\title{
A DIMENSÃO TRANSCENDENTAL NA PRÁTICA PIANÍSTICA: UMA ABORDAGEM INTEGRATIVA TRANSPESSOAL
}

\section{ARTIGO ORIGINAL}

BEZERRA, Denise Maria ${ }^{1}$

BEZERRA, Denise Maria. A dimensão transcendental na prática pianística: uma abordagem integrativa transpessoal. Revista Científica Multidisciplinar Núcleo do Conhecimento. Ano 04, Ed. 08, Vol. 06, pp. 148-183. Agosto de 2019. ISSN: 24480959

\section{RESUMO}

Este artigo é um recorte de uma pesquisa de mestrado em Práticas Interpretativas/Piano, que investigou a autoconsciência do pianista em relação aos estados mentais diferenciados que podem ocorrer durante a prática instrumental, tais como "estado de fluxo" e "experiência culminante". A autora participou como sujeito da pesquisa qualitativa de caráter interdisciplinar, cujo referencial teórico apoia-se na Psicologia e suas ramificações: Psicologia Cognitiva, Psicologia da Música e Psicologia Transpessoal, em conexão com a área da Música. Neste trabalho buscouse observar aspectos de "transcendência" como componentes da prática pianística, à luz do modelo das "sete etapas do desenvolvimento do ser" proposto pela Abordagem Integrativa Transpessoal (AIT). Os resultados sugerem que não só há uma otimização do aprendizado nos aspectos técnicos, quanto há um aprofundamento na dimensão artística bem como um desenvolvimento em diferentes níveis que compreendem a

${ }^{1}$ Doutorado em Engenharia do Conhecimento em andamento (UFSC); Mestrado em Música: Práticas Interpretativas (Piano) (UDESC); Especialização em Educação Musical (UDESC); Especialização em Psicopedagogia Clínica (UNISUL); Especialização em Psicologia Transpessoal (Alubrat/ICPG); Graduação: Comunicação Social (UFSC). 
autorrealização e transcendência do pianista, inaugurando uma perspectiva inovadora na pesquisa em música.

Palavras-chave: Piano, fluxo, experiência culminante, transpessoal.

\section{INTRODUÇÃO}

Tocar piano no nível de expertise consiste em uma ação de alta complexidade. Entende-se que a multidimensionalidade de uma prática pianística eficiente é construída a partir de um conjunto de ações que envolvem o planejamento da execução, estratégias de estudo (BARROS, 2008), bem como a consciência das ações de motricidade e sistemáticas de desempenho (PÓVOAS, 1999, 2006, 2007, 2015). Além destes fatores, aspectos de ordem psicológica estão tecidos nesse sistema complexo.

Este artigo é parte de uma pesquisa de mestrado em Práticas Interpretativas/Piano, que investigou a autoconsciência do pianista em relação aos estados mentais diferenciados que podem ocorrer durante a prática instrumental, tais como "estado de fluxo" e "experiência culminante". A pesquisa qualitativa de caráter interdisciplinar apoia-se no referencial teórico da Psicologia e suas ramificações: Psicologia Cognitiva, Psicologia da Música e Psicologia Transpessoal, em conexão com a área da Música. No presente trabalho interessa focalizar aspectos de "transcendência" como componentes do processo de estudo de um repertório para piano à luz de um modelo fornecido pela Abordagem Integrativa Transpessoal (AIT), oriunda da Psicologia Transpessoal, em sete etapas: Reconhecimento, Identificação, Desidentificação, Transmutação, Transformação, Elaboração e Integração.

\section{A PSICOLOGIA TRANSPESSOAL E A CONTRIBUIÇÃO DE ABRAHAM HAROLD MASLOW}

A Psicologia Transpessoal, mais recente das vertentes psicológicas referendadas neste artigo, responde amplamente às necessidades metodológicas para que se possa analisar os fenômenos mentais de caráter transcendente, tais como os estados 
de platô/fluxo e experiência culminante na prática pianística, em uma dimensão psicológica. É considerada a quarta força da Psicologia e tem como objeto de estudo os estados alterados de consciência. A primeira grande força na Psicologia foi o Behaviorismo, que surgiu em 1913 nos Estados Unidos, por meio de John B. Watson. Em seguida, através de Sigmund Freud veio a Psicanálise, segunda grande força nos estudos mentais. O estudo psicanalítico focalizava principalmente a patologia e o extremo sofrimento diante da própria impotência e limitação humana e desvendou a existência de um inconsciente individual (SALDANHA, 2006). A partir da psicanálise, Carl Gustav Jung (1875-1961) trouxe a noção de que além de um inconsciente individual, existe um inconsciente coletivo. Na mesma época, o psiquiatra italiano Roberto Assagioli (1888-1974) ampliou o conceito de inconsciente, inserindo a dimensão espiritual. Outros autores contestaram ou expandiram a obra freudiana, entre eles Jacob Levy Moreno (1892-1974) - o criador do Psicodrama - e Abraham Harold Maslow (1908-1970). A escola humanista é considerada a terceira grande força na Psicologia e surgiu nos Estados Unidos e na Europa da década de 50, como reação ao Behaviorismo.

Maslow liderou o movimento humanista e em 1968, como presidente da American Psychological Association, convidou para uma reunião Victor Frankl, Antony Sutich, James Fadiman e Stanislav Grof. Nesse encontro oficializou-se a Psicologia Transpessoal, que foi considerada a quarta grande força da Psicologia (idem p.64). Maslow criou então um novo referencial conceitual para legitimar as experiências com estados alterados de consciência, entre elas as experiências culminantes (peak experiences) tal como as descreve:

Os "cumes" mais elevados incluem sentimentos de horizontes ilimitados que se descortinam, o sentimento de ser, ao mesmo tempo, mais poderoso e também mais indefeso do que alguém jamais foi, o sentimento de grande êxtase, deslumbramento e admiração, a perda da localização no tempo e no espaço (idem, ibidem). 


\section{EXPERIÊNCIA CULMINANTE}

A expressão "experiência culminante" (peak experience) foi cunhada por Maslow (1908-1970), que a define como "uma generalização dos melhores momentos do ser humano, os mais felizes da vida, das experiências de êxtase, máximo gozo" (SALDANHA, 2006 p.106). Um dos precursores da Psicologia Transpessoal, Maslow publicou em 1964 o livro "Religions, Values, and Peak Experiences", onde explica detalhadamente o que são as experiências culminantes e suas implicações. Abraham Maslow desenvolveu uma Teoria da Motivação Humana e estudou profundamente os diversos aspectos destas motivações (MASLOW, 1970, 1971) sistematizando a Hierarquia das Necessidades. Ainda que tenha defendido a Psicanálise como o melhor sistema de compreensão psicopatológica e de psicoterapia disponível na época, Maslow afirmou, junto com Jacov Levy Moreno, que Sigmund Freud deteve-se na doença e na miséria humana, e que era necessário "considerar os aspectos saudáveis, os quais dão sentido, riqueza e valor à vida" (SALDANHA, 2006, p. 63). De acordo com Saldanha,

Desde 1943 Maslow já orientou-se para o estudo das motivações, tornando-se um dos mais considerados especialistas em comportamento humano e motivação, pioneiro na sustentação da hierarquia das necessidades e do conceito de autorrealização (idem, p. 72).

Para Maslow, o fenômeno que inclui a explosão do clímax é a experiência culminante ou de pico, diferentemente da experiência de platô. Esta última foi traduzida como "estado de fluxo", por Csikszentmihalyi, que usa um exemplo semelhante, de uma jovem mãe com sua criança, para demonstrar o mesmo efeito:

"Quando estou trabalhando com minha filha, quando ela está descobrindo coisas novas: uma receita nova de bolinhos que ela conseguiu fazer sozinha, um trabalho artístico que a encheu de orgulho. A leitura é outra coisa que ela realmente adora, e nós costumamos ler uma para a outra. Ela lê um pouco para mim, eu leio para ela, e nessas 
ocasiões às vezes chego a esquecer que o resto do mundo existe. Fico totalmente perdida no que estamos lendo" (CSIKSZENTMIHALYI, 2004, p. 37).

Pode-se constatar que elementos da experiência de fluxo descrita por Csikszentmihalyi já haviam sido definidos por Maslow como Experiência de Platô, razão pela qual se adota neste trabalho o termo "platô/fluxo" para denominar tal estado de consciência:

A própria experiência de pico muitas vezes pode significativamente ser chamado de "pequena morte", e um renascimento em vários sentidos. Quanto menos intensa experiência platô é mais frequentemente experimentada como puro prazer e felicidade, como, digamos, em uma mãe sentada em silêncio olhando, por horas, o seu bebê brincando, maravilhada, pensando, filosofando, sem acreditar muito no que vê. Ela pode experimentar isso como uma experiência contemplativa muito agradável e contínua, e não como algo semelhante a uma explosão do clímax que então termina (MASLOW, 1964, p. 4).

Destaca-se que um dos aspectos de maior relevância na pesquisa de Abraham Maslow sobre as experiências culminantes é a constatação de que há uma mudança significativa no comportamento dos indivíduos que vivenciam estas experiências, à qual denominou "autoatualização"[2]. Essas mudanças ocorrem em direção a um ser humano sadio, autorrealizado, cujas características resumidamente são:

- Uma percepção mais clara e mais eficiente da realidade;

- Mais abertura à experiência;

- Maior integração, totalidade e unidade da pessoa;

- Maior espontaneidade, expressividade, pleno funcionamento, vivacidade;

- Um eu real, uma firme identidade, autonomia, unicidade;

- Maior objetividade, desprendimento, transcendência do eu;

- Recuperação da criatividade;

- Capacidade para fundir o concreto com o abstrato; 
- Estrutura democrática de caráter;

- Capacidade de amar (SALDANHA, 2006, p. 69).

\section{O ESTADO DE FLUXO (PLATÔ)}

A Teoria do Fluxo (Flow theory) foi criada pelo psicólogo social húngaro Mihaly Csikszentmihalyi (1934), que inicialmente denominou "teoria sobre uma experiência máxima", fundamentada no conceito de "fluxo" ou

aquele estado no qual as pessoas estão de tal maneira mergulhadas em uma atividade que nada mais parece ter importância; a experiência em si é tão agradável que as pessoas a vivenciariam mesmo pagando um alto preço, pelo simples prazer de senti-la" (CSIKSZENTMIHALYI, 1992, p.17).

Mihaly constatou que a experiência de platô/fluxo se dá quando o indivíduo aproveita conscientemente o momento e pode ser descrita em termos de sete condições básicas:

- As metas são claras: para que a pessoa se envolva por inteiro em qualquer atividade, é essencial que tenha o conhecimento preciso das tarefas que precisa completar, momento a momento. De acordo com o autor, apesar de a meta ser importante,

a verdadeira satisfação reside nos passos que cada um precisa dar a caminho de uma meta, mais do que na conquista propriamente dita (...) e normalmente as pessoas desperdiçam a oportunidade de tirar satisfação do que fazem simplesmente pelo fato de concentrarem toda a sua atenção no resultado em vez de se dedicarem a desfrutar de todas as etapas cumpridas ao longo da missão (id., p. 38).

- O feedback é imediato: para que o estado de platô/fluxo permaneça ativo, é necessário que 0 indivíduo tenha o retorno o tempo todo a respeito dos resultados da sua prática. Para este autor, "a capacidade de proporcionar o 
feedback objetivo a si mesmo é, na verdade, o sinal que distingue o expert' (id., p. 39).

- O equilíbrio entre o desafio e habilidade: quando o desafio e as habilidades estão incompatíveis, o estado de platô/fluxo desaparece, dando lugar à ansiedade e desmotivação (id., p. 40).

- A concentração se aprofunda: numa atividade na qual o indivíduo experimenta as metas passo a passo, com o retorno dos resultados imediatos e compatibilidade entre desafio e habilidades, o envolvimento ultrapassa um determinado nível de intensidade, "não precisamos mais pensar no que fazer, apenas agir de modo espontâneo, quase que automaticamente, mesmo que algum aspecto da tarefa em questão seja muito difícil ou cheio de riscos" (id., ibidem). Nesse estado de platô/fluxo, a consciência e ação fundem-se numa interminável onda de energia. A concentração no flow chega a ser tão profunda que o termo "êxtase" pode ser usado para descrevê-la (id., p. 42).

- O que importa é o [foco no] presente: para que o estado mental seja de platô/fluxo, "a tarefa em andamento exige total atenção, as preocupações da vida rotineira não conseguem lugar para entrar na mente" (id., p. 43). Ou seja, o foco absoluto na atividade evita que o platô/fluxo seja interrompido.

- A noção do tempo é alterada: a noção do tempo fica distorcida, o que parece 15 minutos foi na realidade 2 horas; ou o contrário, permaneceu 15 minutos na atividade, mas com tal profundidade que parece ter ficado 2 horas (id., p. 45).

- A perda do ego: quando imerso na experiência de platô/fluxo, o indivíduo tende a esquecer não só os problemas e circunstâncias que o cercam, mas a própria individualidade. Torna-se mais consciente do próprio corpo, mas deixa de lado sua identidade social - nome, título e responsabilidade implicada por ele - e transcende da individualidade para a "oportunidade de assumir um envolvimento ativo em algo maior do que o ego, sem com isso renunciar a qualquer das habilidades mentais, físicas ou volitivas do indivíduo" (id., p. 47). 


\section{EXPERIÊNCIA CULMINANTE E EXPERIÊNCIA DE PLATÔ/FLUXO NA PRÁTICA PIANÍSTICA}

O estado de fluência experimentado por uma criança enquanto brinca pode ser concebido como o mesmo estado mental do pianista quando "brinca" em seu instrumento, e nos leva a uma possibilidade de desempenho extremamente natural $\mathrm{e}$ orgânica, além de divertida. Csikszentmihalyi descreve tal processo (fig. 1), onde "A" é um menino que está aprendendo a jogar tênis, em quatro momentos diferentes. Inicialmente apenas consegue fazer a bola atravessar a rede (A1) e mantém-se no estado de platô/fluxo, o que realiza durante alguns meses até ficar entediado (A2). Quando desafiado por um adversário mais experiente, entra num estado de ansiedade (A3) ao constatar o próprio desempenho como inferior, estabelecendo a si mesmo novas metas, que o levam de volta ao estado de platô/fluxo (A4) (CSIKSZENTMIHALYI, 2008). No estudo do piano, é possível constatar esta mesma dinâmica proposta pelo autor. Para observar a experiência de platô/fluxo no estudo do piano, foram selecionados neste trabalho dois tipos de estratégia de estudo: rodízio das partes e a repetição consciente. O rodízio é um sistema no qual a peça a ser estudada é dividida em partes que são organizadas e estudadas separadamente, e intercaladas com outras peças ou partes de peças. Cada uma das partes deve ser executada por períodos de tempo em torno de 20 a 30 minutos cada, fazendo o rodízio (A1). 
Figura 1: Gráfico de desafio/habilidades, de Mihaly Csikszentmihalyi.

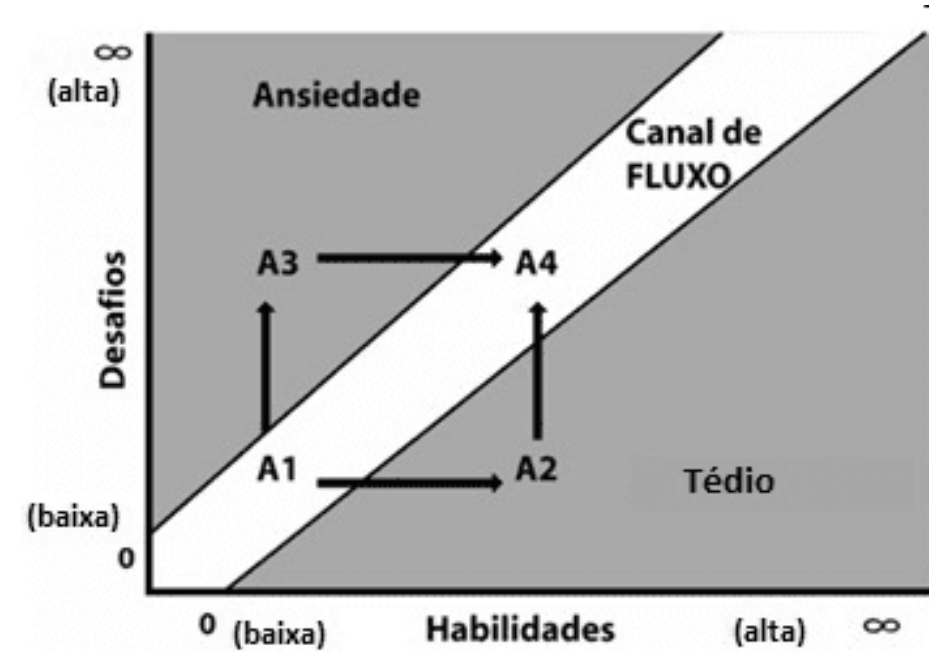

Fonte: CSIKSZENTMIHALYI, 2008, p. 74.

Já a repetição consciente consiste em realizar cada uma das partes inúmeras vezes, desde que a ação ocorra com máxima atenção, evitando o estado de devaneio. A característica de "jogo" desta combinação de estratégias de estudo cria uma dinâmica cujo objetivo não é tocar a peça do início ao fim, mas estar em contato com toda a obra, esmiuçando cada parte, garantida pelo rodízio (A3, A4). Desta forma, pode-se constatar o alcance das seguintes condições necessárias ao estado de platô/fluxo: a) equilíbrio entre desafio e habilidade (garantida pela repetição consciente de partes pequenas) (A1); b) o que importa é o foco no presente (a ansiedade de ter que tocar a obra toda é neutralizada pelo compromisso de tocar apenas o pequeno trecho selecionado) (A3, A4); c) metas claras passo a passo (a delimitação de partes menores e com tempo definido traz segurança a cada trecho completado)(A4); d) feedback imediato (ao repetir o trecho com tempo delimitado, o indivíduo pode, a cada vez, avaliar o seu desempenho e utilizar habilidades metacognitivas de automonitoramento e autorregulação, componentes da motivação (A1, A2, A3, A4). Com estas competências em ação, o estado de platô/fluxo tende a se estabelecer, aumentando a intensidade através da automatização, levando ao ponto em que a concentração se aprofunda. A partir daí, a perda da noção do tempo vem seguida da perda do ego. O indivíduo fica totalmente entregue à atividade, que pode durar alguns 
instantes ou até mesmo muitas horas. "Platô [fluxo] é diversão" (PRIVETTE, 1983, p. 1364).

As situações de platô/fluxo na prática do piano mantêm o indivíduo em um estado mental que possibilita e favorece a concentração cada vez mais intensa, levando à consciência plena da interação do corpo, cognição e emoções, elementos essenciais à interpretação de uma obra pianística. Quanto mais eficiente esta interação, maior o equilíbrio do artista na sua realização. Estes requisitos proporcionam ao pianista atingir estados de consciência ampliados, o que na ótica de Abraham Maslow, leva a uma autoatualização em direção à autorrealização. Um pianista que consegue trilhar esse caminho e experimentar com frequência estas vivências adquire a possibilidade de estabelecer contato com dimensões muito mais profundas do seu próprio ser, bem como da própria obra de arte. Depoimentos de pianistas como a portuguesa Maria João Pires ao tentar descrever o que ocorre durante a interpretação pianística, definem:

Nós temos de acreditar que um milagre pode acontecer. E eles acontecem, mais e mais, quando você acredita... Música é o sinal de que milagres existem. A luz em toda a sua alma se abrindo para algo desconhecido, você vai... apenas vai... É muito importante, não podemos dizer não a algo se esse algo existe. ${ }^{[3]}$

Esse estilo de linguagem utilizada pela pianista na tentativa de relatar o fenômeno é característico na descrição de uma experiência culminante. A inefabilidade é um atributo das experiências transcendentes, difíceis de ser traduzidas com palavras.

O relato de um compositor contemporâneo apresenta semelhança na descrição:

Você atinge um êxtase tão profundo que chega ao ponto de imaginar que deixou de existir. Eu já tive essa experiência inúmeras vezes. É quando minha mão se movimenta sem qualquer comando, e eu aparentemente nada tenho a ver com o que está acontecendo. Fico apenas ali sentado, observando num estado de reverência e 
encantamento. E (a música) flui por conta própria (CSIKSZENTMIHALYI, 2004, p. 43).

Na prática do piano, é possível experimentar momentos de intensa gratificação e prazer, resultantes de uma profunda experiência estética, tanto para quem toca quanto para quem ouve. Com a perspectiva apresentada por Abraham Maslow de auto atualização através da ocorrência frequente destas experiências, o pianista dispõe da oportunidade de adequar à sua prática uma dimensão muito mais ampla do seu próprio ser, da sua conexão com a obra e o compositor, além de ressignificar a sua relação com o público; tal situação transcende à simples experiência estética (ligada aos sentidos).

Esta temática é analisada com base nos autores de orientação transpessoal, Abraham Harold Maslow (1968), Pierre Weil (1995), Roberto Assagioli (1993, 2013), Vera Saldanha $(2006,2008)$ e Ken Wilber $(2010)$, que corroboram a ideia de que a consciência pode ser expandida. Por outro lado, Mihaly Csikszentmihalyi entende por alteração de consciência a simples sensação de vertigem causada por um indivíduo que começa a girar em torno do próprio eixo e fica tonto. Para este autor, não é possível expandir ou ampliar a consciência, apenas embaralhá-la. Nas suas palavras, "A consciência não pode ser expandida; tudo o que podemos fazer é embaralhar seu conteúdo, o que nos dá a impressão de tê-la ampliado de alguma forma" (CSIKSZENTMIHALYI, 1992, p. 112).

Embora discordemos desta proposição, admite-se a utilização dos indicadores do estado de platô/fluxo classificados pelo autor, descritos anteriormente, uma vez que não representam uma contradição. Desta forma, o conceito de "estado de consciência" é assim definido na perspectiva da Psicologia Transpessoal:

Estados ou níveis de consciência simbolizam, no corpo teórico, o caminhar através das diferentes dimensões da consciência. São passos que norteiam o processo, ampliam e favorecem a percepção de diferentes níveis de realidade. É o caminho através do qual se dá essa prática na área clínica, na educação, em grupos, e outras áreas nas 
quais se queira dar uma orientação transpessoal. É um dos elementos que a diferencia de outras abordagens (SALDANHA, 2006, p. 118).

\section{ABORDAGEM INTEGRATIVA TRANSPESSOAL (AIT)}

A Abordagem Integrativa Transpessoal (AIT), foi sistematizada pela psicóloga brasileira Vera Saldanha a partir dos principais conceitos da Psicologia Transpessoal, ampliando-os e apresentando-os de forma estrutural e dinâmica, para possibilitar sua aplicação na educação, saúde e instituição, facilitando sua leitura e compreensão. Saldanha denominou a elaboração desse conhecimento em Psicologia como Abordagem Integrativa Transpessoal e sua forma de ensiná-la como Didática Transpessoal. Para este trabalho, descrevo as sete etapas elaboradas pela autora da AIT em conexão com a prática pianística, aplicando algumas técnicas psicológicas e ferramentas de análise. O referencial teórico proposto por essa abordagem cumpre a tarefa de capturar a experiência musical como evento científico e requer um protocolo que contemple sua característica subjetiva, amplamente favorecida no enquadre da Didática Transpessoal, originada a partir da Abordagem Integrativa Transpessoal (AIT).

Dois dos conceitos que fundamentam os aspectos dinâmicos desta abordagem são aqui apresentados: R.E.I.S. (razão, emoção intuição e sensação) e eixo experiencial/evolutivo. O eixo experiencial simboliza uma integração dos quatro elementos do desenvolvimento psíquico - razão, emoção intuição e sensação (REIS) - representado por uma linha horizontal sobre outra linha vertical que se cruzam ao meio (idem), conforme gráfico abaixo: 
Figura 2. Gráfico Eixo experiencial e eixo evolutivo.

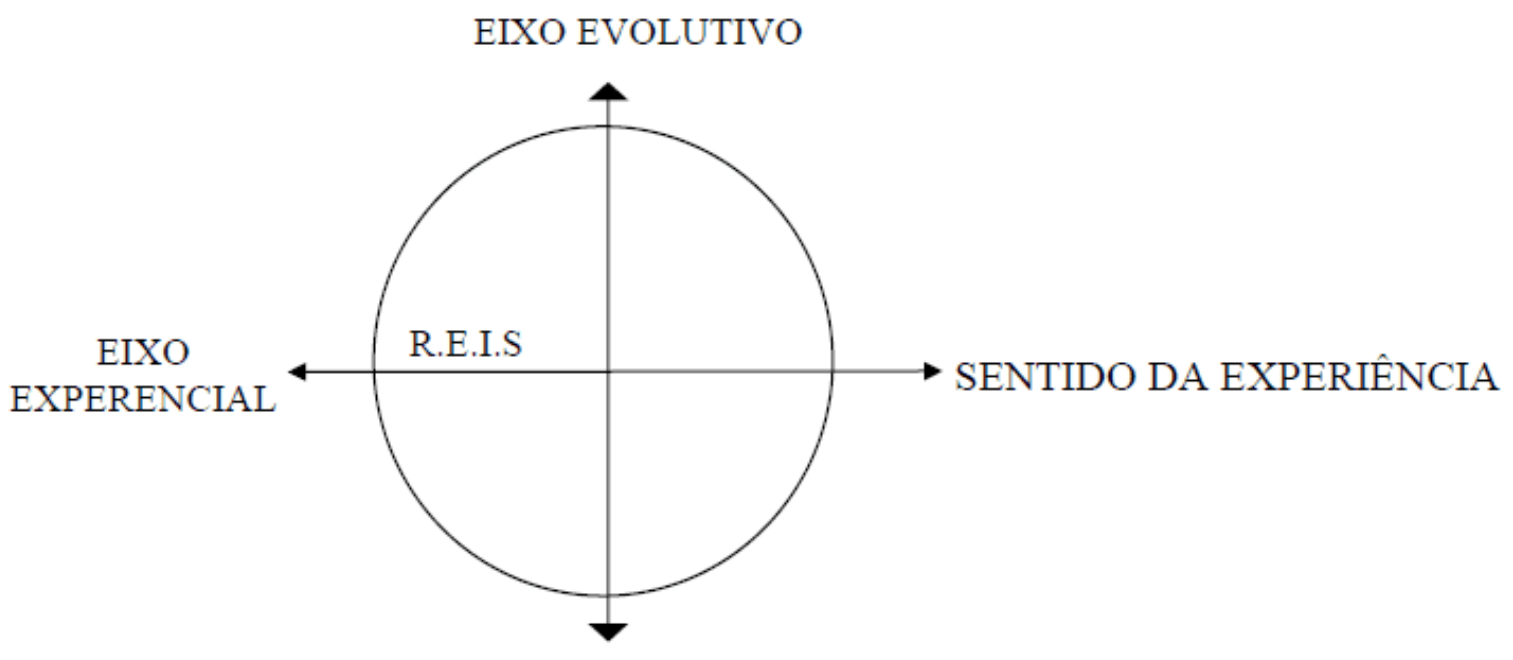

UNIDADE

Fonte: SALDANHA, 2006, p. 142.

A construção do axioma apoia-se, em alguns aspectos, no referencial junguiano dos tipos psicológicos ${ }^{[4]}$. Entretanto, no enfoque transpessoal da AIT, as funções psíquicas são consideradas elementos do desenvolvimento psíquico e trazem uma perspectiva ampliada dos conceitos de Razão, Emoção, Intuição e Sensação ${ }^{[5]}$. Nesta abordagem, a emoção é considerada altamente desejável, e incorpora a concepção biológica do conhecimento e do amor, desenvolvidas por Humberto R. Maturana ${ }^{[6]}$, a autora incorpora ao referencial da AIT a noção de amor como

uma condição fundamental, biológica e relacional na educação e na saúde humana. Além disso, a emoção é essencial por conferir à situação o aspecto experiencial, trazer a energia necessária ao processo de desenvolvimento psíquico, favorecer a aprendizagem. Somente será danosa, se o indivíduo se mantiver fragmentado e identificado só com a emoção, o que impedirá a manifestação e integração de outras funções psíquicas e elementos do desenvolvimento humano (SALDANHA, 2008, p. 188). 
À luz deste modelo, pode-se afirmar que o eixo experiencial trata da evolução nos aspectos empíricos, ligados à prática de técnicas e exercícios, integrando razão (pensamento), emoção (sentimento), intuição e sensação.

Ao praticar frequentemente em seu instrumento, o pianista dá o primeiro passo para aflorar componentes mais profundos do psiquismo e integrá-los à consciência de vigília, permitindo uma expressão mais saudável da psique (idem). Já o eixo evolutivo concerne aos aspectos éticos, aos valores do ser (S), e acessa estados de consciência ampliados, num estágio denominado "ordem mental superior" (OMS). No nível da OMS ocorrem os insights e ocorrem as experiências de cume e platô/fluxo, para mais tarde serem integrados à consciência de vigília.

De acordo com Maslow, a criatividade primária é a fase da inspiração, do insight criativo, ou seja, do nível da OMS; e que a segunda fase, a criatividade secundária, consiste na elaboração e desenvolvimento do material fornecido pela primeira fase,

no trabalho árduo, na disciplina do artista que pode dedicar meia vida a aprender seus recursos, seus meios e seus materiais até estar pronto para a plena expressão do que vê. (...) As virtudes que acompanham a criatividade secundária, a que tem por resultados os produtos reais, os grandes quadros, as grandes novelas, as pontes, os novos inventos, etc., se apoiam tanto em outras virtudes - obstinação, paciência, laboriosidade - como na criatividade da personalidade (MASLOW, 2008, p. 85).

No enfoque da Abordagem Integrativa Transpessoal (AIT), existe ainda um processo terciário

definido como um conjunto de referenciais inerentes ao desenvolvimento do ser humano que favorece o despertar da dimensão espiritual, propiciando a atualização experiencial de valores positivos, saudáveis, curativos tanto individual como coletivo, caracterizando um processo regido pelo princípio da transcendência (SALDANHA, 2008, p. 144). 
$\mathrm{Na}$ ótica da Abordagem Integrativa Transpessoal admite-se a existência de uma "pulsão para a transcendência" no ser humano, conceito formulado por Vera Saldanha, com base nos estudos de Abraham Harold Maslow. Na prática pianística, esta pulsão mobiliza o pianista em busca de sua autorrealização, seja no estudo de uma peça curta, seja numa obra integral, ou ainda, ao longo de toda a sua trajetória. Anterior à satisfação das necessidades básicas e meta necessidades no estudo do piano, reside uma pulsão, algo que alimenta a motivação para tocar e aprimorar-se cada vez mais.

Nessa perspectiva, a ação pianística consiste na interação entre as três etapas da criatividade, que ocorre de uma forma não linear e dinâmica, e sem a qual não é possível construir uma prática em nível de expertise e do desenvolvimento do ser, simultaneamente. Na primeira e segunda etapas são supridas as necessidades que Maslow denominou como básicas ${ }^{[7]}$. Na proposição da AIT, seriam atendidas as necessidades mais básicas do pianista, de sobrevivência e segurança (primária) e de ser reconhecido e de autoestima (secundária). Surgem então novas necessidades, de autorrealização e autoatualização, quando emerge o processo terciário. Nesse nível a pulsão da transcendência pode se expressar, e abrange tanto as necessidades básicas quanto as metanecessidades, holocentradas, ou seja,

centradas no todo, nas quais há valores positivos naturalmente éticos, como a solidariedade, beleza, êxtase e a própria espiritualidade presentes como aspectos inclusivos do desenvolvimento humano (SALDANHA, 2008, p. 147).

Aproximando esta abordagem à prática pianística, o eixo experiencial contempla o estudo do piano propriamente dito, o emprego de estratégias cognitivas, a estimulação do REIS, a aplicação de técnicas de otimização dos movimentos, aulas de piano e de áreas afins, apresentações públicas, ou seja, toda a experiência prática. Já o eixo evolutivo, que se manifesta concomitantemente ao experiencial, diz respeito à metamotivações e aspectos subjetivos, acessados na dimensão do supraconsciente. São aquelas experiências musicais que atingem um patamar de transcendência e plenitude, em diferentes graus de intensidade, tais como o estado de platô/fluxo, 
experiências culminantes, exercícios de imaginação ativa aplicados à prática pianística, dentre outras. O resultado dessas vivências é a conexão com valores internos que promovem uma evolução integral do ser (S), tal como referendado por Maslow. De acordo com a autora da Didática Transpessoal,

As dinâmicas utilizadas inserem o estímulo aos recursos interiores que o próprio indivíduo tem e que podem ser acessados sob certas circunstâncias. Esse manancial é o ponto central do trabalho nesta abordagem, é a própria manifestação da ordem mental superior ou supraconsciente (...). Essa instância psíquica apreende a realidade de forma lúcida, sabe aquilo que é necessário e melhor para nós em nossa jornada no processo de aprendizagem, na cura mental e física. Esse acesso, contudo, não é tão simples ou fácil e, em geral, precisa ser favorecido (id.: p. 140).

A interação entre estes aspectos dinâmicos do psiquismo do pianista resulta em um processo que obedece a uma série de etapas. Saldanha elaborou uma classificação em sete etapas relacionadas ao processo de desenvolvimento do ser:

São etapas de uma técnica, a que denominamos interativa, e são também etapas integrativas de um processo de desenvolvimento pessoal, estando vinculadas às necessidades básicas da teoria da motivação, descrita por Maslow, e relacionadas por Weil, aos sete centros do desenvolvimento psíquico e transpessoal (SALDANHA, 2006, p. 161).

As etapas são subsequentes e analisadas de forma linear para efeito didático, mas podem ocorrer de forma simultânea: 1- Reconhecimento; 2- Identificação; 3Desidentificação; 4- Transmutação; 5- Transformação; 6- Elaboração; 7- Integração. O fator "desenvolvimento" do ser, que está na base da proposição desta didática, é compatível com o desenvolvimento ocorrido durante o processo de aprendizagem e construção de uma obra, na ação pianística, o que favorece a sua correlação. $O$ aspecto transcendental da experiência musical é então observado por esse viés, 
razão pela qual não nos limitamos ao construto da Psicologia tradicional, uma vez que este não aborda tal conceito.

A partir do modelo proposto pela autora da AIT, faz-se uma análise de situações envolvidas na ação pianística. Ao atravessar as sete etapas deste processo, do reconhecimento à integração, ocorrem no pianista mudanças de ordem intrínseca, promovidas pela alteração no aspecto prático, bem como na dimensão psicológica.

\section{AS SETE ETAPAS DO PROCESSO TRANSPESSOAL NA AÇÃO PIANÍSTICA}

"Processo" é uma palavra que deriva do latim Processus, projeção, descende de Pro, para frente e Cedere, ir; está relacionada com percurso, e significa "avançar" ou "caminhar para frente". Deste modo, entende-se neste trabalho que o avanço, o caminhar para frente no trabalho com uma obra musical em fase de estudo ou de manutenção, consiste num processo concomitantemente psicológico, durante o qual ocorrem com o pianista mudanças em diversos níveis do ser, mediante a interação dos elementos do desenvolvimento psíquico (razão, emoção, intuição e sensação: REIS).

A aproximação da Abordagem Integrativa Transpessoal com a área de Práticas Interpretativas fundamenta-se na evidência de que existe um processo psicológico inerente àquele de preparação de uma obra pianística. De acordo com Barros,

O processo de preparação de um repertório pianístico que culmina com a sua execução é um campo de pesquisa relevante para a área de Práticas Interpretativas, pois o resultado final dessa execução depende, incondicionalmente, do trabalho precedente (BARROS, 2008, p. 2).

Observe-se que em uma abordagem psicológica, é de especial interesse analisar o processo, fonte de dados importantes para análise, além dos resultados. A descrição desse processo à luz da Abordagem Integrativa Transpessoal é aqui apresentada com base na sistematização em sete etapas, criada pela psicóloga Vera Saldanha. São 
sete etapas de uma técnica que a autora denomina integrativa, e são também etapas interativas de um processo de desenvolvimento pessoal. As etapas estão vinculadas à teoria da motivação, descrita por Maslow, cujo desenvolvimento em sete etapas encaminha-se em direção à autorrealização, estimulado pela pulsão de transcendência (SALDANHA, 2006). Entende-se que os conceitos apresentados no percurso desta investigação oferecem suporte para a análise e compreensão da ação pianística no processo transpessoal nas sete etapas, descritas a seguir:

\subsection{PRIMEIRA ETAPA: RECONHECIMENTO}

Esta etapa consiste em um primeiro encontro, o primeiro contato, quando o pianista interage com a obra musical em questão, de acordo com o seu perfil de interesse, ou conforme Saldanha, "um olhar ao redor" (idem, p. 162). A obra pode ser nova para o pianista, como pode ser uma retomada, um novo ciclo de sete etapas de algo já conhecido anteriormente. Cada pianista, conforme o nível de expertise, experiência com métodos de estudo e personalidade, vivencia essa etapa de forma particular. $\mathrm{O}$ pianista americano Murray Perahia declara que ao começar uma nova peça para piano, toca-a repetidas vezes, sem pensar em estrutura e análise, apenas envolvendo-se com a obra. O pianista brasileiro Nelson Freire afirma que a condição para que decida estudar uma nova peça é estar apaixonado por ela; do contrário, sente-se como uma "toupeira"[8].

Nessa fase de contato inicial algumas impressões a respeito da peça vão delineando o vínculo entre o pianista e a obra. É de fundamental importância ter em vista, como metacognição e autorregulação, qual a motivação em aprender uma nova peça. O que o pianista pretende, conscientemente ou não, ao escolher esta peça, neste momento. Perguntas fundamentais para serem feitas nesta primeira etapa são: "Por que eu escolhi esta peça?"; "O que eu almejo conseguir com esta peça?"; "O que esta peça representa para mim?"; "Qual o momento que estou passando atualmente, enquanto estou aprofundando meu contato com essa obra?"; "Que mudanças terei experimentado após concluir o estudo completo desta peça e o que vai alterar na minha vida?". Uma atitude autoconsciente demanda um questionamento desde o 
início da escolha do repertório, através das capacidades metacognitivas de autoobservação, automonitoramento e autoavaliação.

$\mathrm{Na}$ etapa do reconhecimento são manipulados os primeiros elementos musicais da obra, sua estrutura geral, temas, andamento, caráter; é o momento de analisar e selecionar os trechos, marcar dedilhados, estudar movimentos de otimização na ação pianística. Nesse estágio ocorre

uma mobilização interna, uma motivação que pode ser desencadeada por estímulos intrínsecos ou extrínsecos. Em relação à motivação, é o momento em que há uma lacuna, um espaço de desconhecimento diante de algo novo, não aprendido, que segundo Maslow, insere-se nas necessidades básicas (SALDANHA, 2006, p.162).

A autoconsciência em relação à etapa inicial do aprendizado, independente do grau de expertise do pianista, revela-se crucial para evidenciar possíveis dificuldades inconscientes, que possam estar latentes. Nessa etapa há uma ebulição de elementos musicais, uma seleção daquilo que já se sabe e daquilo que é novo, um despertar dos elementos do desenvolvimento psíquico, chegando a um aparente caos. Talvez ocorra uma afinidade imediata com determinado tipo de repertório ou uma aversão ao primeiro contato com certas obras ou ao contrário, pode surgir uma dificuldade em experimentar algo novo, diferente, que fuja à comodidade de trabalhar um repertório próximo daquilo que já é conhecido. A ansiedade que acompanha "o novo" deve ser controlada através dos mecanismos de metacognição, por ser uma emoção ligada ao medo, o que pode inibir a motivação e, consequentemente, o desempenho do pianista. Salienta-se que conforme o nível de motivação é possível alcançar o estado de platô/fluxo já na primeira etapa, desde que a interação pianista/obra/instrumento transcorra de forma agradável e salutar.

Uma etapa de reconhecimento realizada satisfatoriamente permite a transição para a etapa seguinte, a identificação, uma vez que não se pode identificar algo sem antes o reconhecer. A primeira etapa sedimenta o caminho para as etapas seguintes, 
portanto, quanto mais proficiente for o trabalho realizado nessa fase, maiores serão as chances de autorrealização nas próximas etapas.

\subsection{SEGUNDA ETAPA: IDENTIFICAÇÃO}

Após reconhecer e intensificar o envolvimento com a obra, o pianista passa a aprofundar o seu vínculo com o objeto em questão, ou seja, passa a identificar-se com a obra como um todo, com o estilo e/ou com o compositor. Relaciona as partes identificadas com sua experiência prévia, manipulando os elementos de forma gradativa e cumulativa. A identificação pode ser entendida como uma afinidade do pianista em relação à obra ou aspectos da mesma. A fase da identificação determina se o pianista levará adiante o estudo da obra ou não, despertando seus elementos do desenvolvimento psíquico, razão, emoção, intuição e sensação e sustentando a motivação, a qual visa suprir as necessidades básicas. Portanto, a formação de um vínculo positivo com a obra e com o fazer artístico envolvido nesse momento consistem em fatores preponderantes para sustentar a motivação e dar continuidade do processo.

Por exemplo, o caso de um pianista que esteja carente no aspecto de pertencimento, na hierarquia das necessidades, e que decida incluir no seu repertório uma obra de trio com piano, alimentado pela motivação de pertencer a um grupo e ser aceito por ele. Mesmo que este pianista ainda não tenha encontrado os integrantes para formar o trio, mantém-se motivado por estar identificado com a possibilidade intrínseca oferecida pela música de câmara. Estabelece-se um vínculo positivo com a obra e o seu entorno, consolidando a identificação.

Saldanha destaca que

a identificação só acontece se houver uma ressonância com a necessidade básica na qual o indivíduo se encontra; então, ocorrerão a participação, interesse ou, caso contrário, abandono. O conhecimento fica só como mera informação intelectual, disfuncional, aquela informação decorada, superficial, que é pouco aproveitada para a vida 
do indivíduo e, geralmente, é logo esquecida. Se há o envolvimento, a participação do emocional aliada ao cognitivo, sensorial e intuitivo, mobilizam-se as estruturas ligadas a aprendizagem e à sua aquisição (SALDANHA, 2008, p. 163).

De fato, caso não haja uma identificação do pianista e a formação de vínculo positivo com a obra, pode ocorrer o abandono do estudo da peça. Tal situação é evidenciada pelo sentimento de desânimo em relação à obra, o que seria contornado com uma postura autoconsciente por parte do pianista. A falta de identificação com a proposta do autor pode traduzir-se em uma dificuldade para memorizar um trecho ou a peça completa; da mesma forma, ainda que consiga memorizar facilmente, porém mantenha uma interpretação pouco musical, fria e distante, isso pode ser o resultado de baixo nível de identificação, em função de não encontrar a motivação artística que se traduza em uma expressão musical no trecho ou na peça inteira.

$\mathrm{Na}$ ação pianística é possível observar nitidamente o momento em que a identificação se faz presente. Um exemplo disso acontece em minha prática ao trabalhar um trecho de elevada dificuldade, seja de ordem técnica ou interpretativa. O processo transcorre da seguinte forma: detenho-me diante do trecho, ao piano, e procuro observar quais os elementos envolvidos naquela ação pianística. Numa perspectiva autoconsciente, observo o meu estado de consciência no momento, e minha interação com a peça e com o piano. Seleciono o trecho com a dificuldade ao mesmo tempo em que vou buscando soluções cognitivas para minhas indagações; mantenho-me num estado de receptividade, permitindo que fluam as respostas, mesmo aquelas que parecem descartáveis. Nesse momento, há o favorecimento ao estado de platô/fluxo. Desta forma, procuro trabalhar a parte selecionada com a maior lógica possível, respeitando as sugestões de movimento, obedecendo aos insights momentâneos, deixando fluir até que surja a resposta. A partir daí, cria-se um vínculo inexorável com aquele trecho. A segurança posterior resultante desse processo permite que as conexões sejam cada vez mais fortes e a identificação ocorra de forma eficiente.

Para essa análise, selecionei um excerto de uma peça do repertório que preparei no curso de mestrado em Práticas Interpretativas, a Balada no 1, de Chopin, compassos 
223-242 (fig. 6). Segundo Alfred Cortot em sua Édition de Travaille, nessa coda encontram-se as mais evidentes complicações técnicas da Balada ํㅜ 1, que o autor considera de difícil execução do triplo ponto de vista: da resistência dos dedos, da flexibilidade do pulso e da extensão (CORTOT, 1929, p. 18). De fato, deparei com uma situação que requer uma ação pianística plena. Para cumprir tal tarefa, adotei o procedimento visando a identificação conforme o

Figura 3. Excerto da Balada ํo 1, de F. Chopin (comp. 223-242).
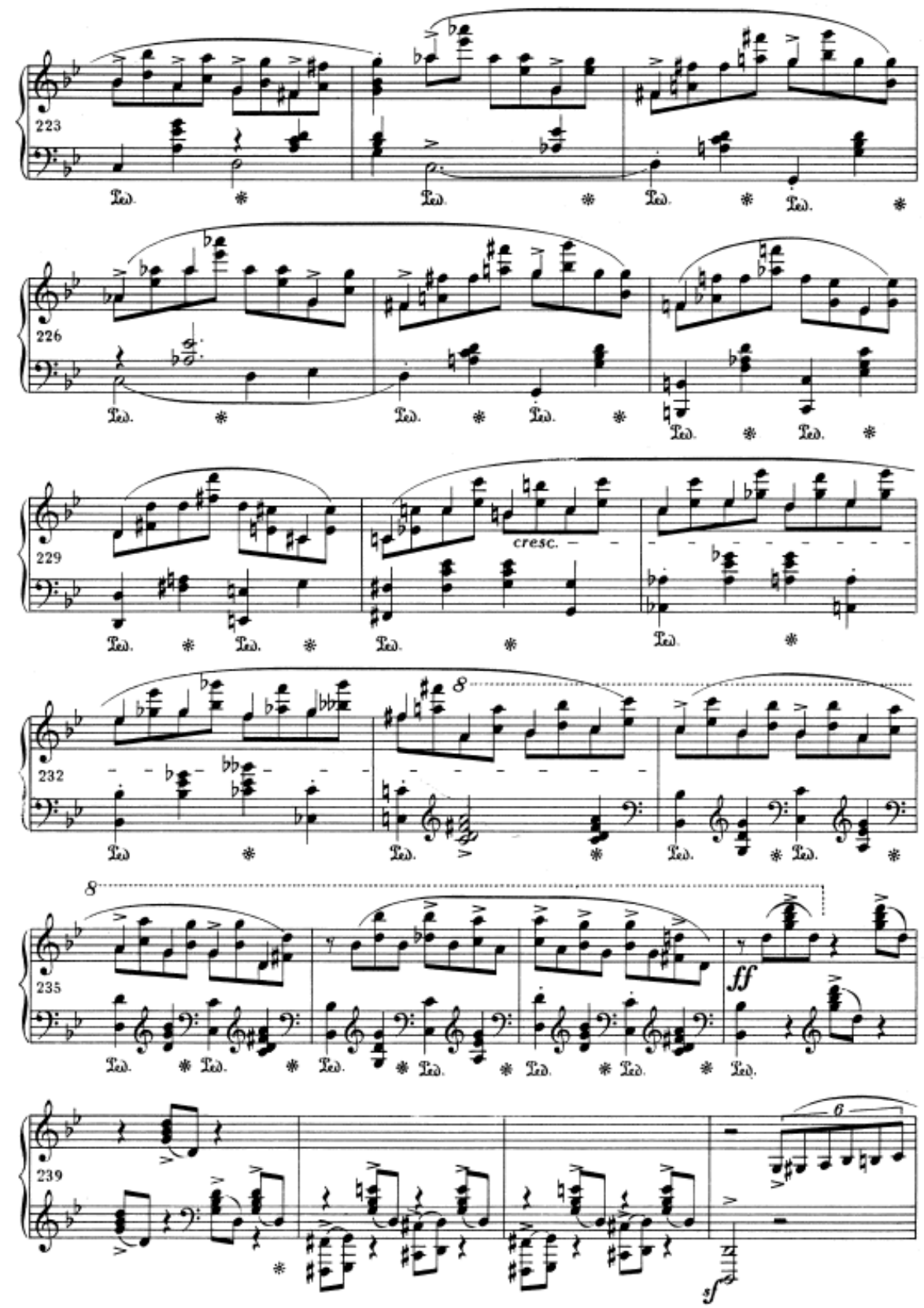
Fonte: imslp.org.

descrito anteriormente e aguardei a emergência das respostas cognitivas. Para atingir a proposta do compositor, busquei adequar os movimentos a partir da escrita, considerando os apoios e deslocamentos. Embora tenha lançado mão de uma série de estratégias de estudo, tais como estudo lento, estudo de mãos separadas, estudo com metrônomo, estudo de trás para frente, aplicação dos ciclos de movimento ${ }^{[9]}$, ainda não conseguia realizar o "presto com fuoco" sugerido pelo compositor.

Não estava encontrando as respostas para superar minha dificuldade, até que ocorreu um fato interessante após duas aulas de piano, em duas semanas consecutivas. $\mathrm{Na}$ primeira, apresentei as Variações Corelli, de Rachmaninoff, com um desempenho adequado, que foram bastante elogiadas pela professora. Meu nível de motivação elevou-se ainda mais, suprindo as necessidades básicas de pertencimento e estima da hierarquia proposta por Maslow. Na segunda aula, uma semana depois, apresentei a Balada $n^{\circ} 1$, de Chopin. Para minha surpresa, meu desempenho foi o oposto àquele obtido na aula anterior, com falhas de interpretação, interrupções e hesitações. Obviamente a professora fez uma série de intervenções, buscando

otimizar minha performance, a qual considerei débil. Após a aula, observei meu nível de motivação despencar, e lancei mão de minhas estratégias metacognitivas de autoavaliação, automonitoramento e auto-observação.

Dias depois, durante uma experiência de platô/fluxo em uma sessão de estudo, ocorreu uma catarse ${ }^{[10]}$ da qual emergiu do supraconsciente a resposta que eu estava aguardando. Entendi que a defasagem entre uma aula e outra tinha origem em um problema de outra ordem: a obra "Variações Corelli", de Rachmaninoff é uma peça nova para mim, e a "Balada n 1", de Chopin, é uma peça que venho "tentando tocar" desde a infância. A partir desse entendimento, outras respostas emergiram em forma de uma pequena história de minha relação com esta obra, tal qual Assagioli descreve a respeito da abertura do supraconsciente (ASSAGIOLI, 1993).: 
Rememorei o fato completo de que aos 10 anos de idade ganhei o álbum com obras de Chopin; ouvia a gravação em disco (LP) e acompanhava na partitura; aventureime no piano, e o fazia saltando de um trecho a outro, evitando tocar as partes mais complexas; por fim, acabei deixando de lado a peça por achar "impossível" de tocar. Décadas se passaram e surgiu a vontade de estudar a balada no curso de mestrado, com a aprovação de minha professora. Desde o insight que provocou a catarse, procurei lembrar-me de como me sentia em relação à peça na infância, ou seja, qual o tipo de vínculo foi estabelecido no processo de identificação. Percebi que internalizei uma série de crenças limitadoras, as quais reforçaram o vínculo negativo de identificação, alimentando uma carência básica ${ }^{[11]}$, ao invés de suprir uma necessidade básica. Desde então estas crenças limitadoras ficaram cristalizadas em meu inconsciente, sabotando meu processo de autorrealização. Minha perspectiva infantilizada manteve-se intacta, porém, inconsciente, reforçando as seguintes crenças:

- A peça é muito longa e de difícil execução;

- É muito rápida, impossível de tocar;

- Há notas demais para memorizar;

- Pertence a um nível muito avançado de desempenho.

Ao aflorar para a consciência, ficou evidente que esse material psíquico era suficiente para impedir, numa dimensão psicológica, que meu desempenho fosse adequado. Nesse momento, houve uma integração da identificação, quando "há o envolvimento, a participação do emocional aliado ao cognitivo, sensorial e intuitivo" (SALDANHA, 2006, p. 225) ou o que os psicólogos denominam "fechamento da Gestalt" [12]. Até o presente momento foi vivenciado o eixo experiencial e pode-se dizer que se completou um quebracabeças, no qual a soma das partes é maior do que o todo. No uso de minhas habilidades metacognitivas, percebi a necessidade de aprofundar meu processo autoconsciente e buscar mais respostas que se revertessem em uma otimização de meu desempenho na balada de Chopin. Desta forma, o próximo passo seria desconstruir imediatamente tais crenças limitadoras, substituindo-as por novos pensamentos que fossem construtivos e que preenchessem minhas necessidades. 
Estaria me preparando para o processo de desidentificação dos padrões antigos. Nesse momento há uma integração dos elementos identificados, para criar um vácuo que leva à desidentificação, criando um distanciamento, colocando-os em perspectiva. Para alcançar essa desidentificação, as crenças limitadoras já identificadas deveriam passar a ser vistas com distanciamento, para que pudessem ser desconstruídas e favorecer essa próxima etapa.

A técnica utilizada para neutralizar as crenças limitadoras foi a "afirmação" e consiste em reescrever cada frase de forma construtiva, realizando os câmbios psicológicos adequados:

- "A peça é muito longa e de difícil execução" foi substituída por "Consigo executar cada trecho da peça com facilidade do início ao fim";

- "É muito rápida, impossível de tocar" foi substituída por "Possuo técnicas adequadas para realizar com facilidade os trechos rápidos";

- "Há notas demais para memorizar" foi substituída por "Sei todas as notas de memória, elas simplesmente aparecem em minha mente";

- "Pertence a um nível muito avançado de desempenho" foi substituída por "A peça é muito avançada e está dentro das minhas possibilidades de desempenho".

As afirmações são adaptativas, com um conteúdo livre de limitações psicológicas e foram repetidas diariamente durante uma semana, a todo o momento: mentalmente, em voz alta, ao piano e longe dele. Assagioli destaca que o ato de afirmação consiste

numa ordem ou declaração feita pela pessoa a si mesma. É o uso do tempo imperativo, por meio de palavras tais como o latim fiat ${ }^{[13]}$ ou "assim seja". A intensidade ou "voltagem psicológica" da afirmação determina o grau e a extensão de sua eficácia (ASSAGIOLI, 2013, p. 140). 
Ao longo daquela semana, observei a evidente alteração de minha atitude em relação à balada de Chopin, e, consequentemente, a mudança positiva em meu desempenho, o que foi possível constatar nas aulas seguintes de piano.

No momento em que percebo que tenho uma dificuldade, mas não sou a dificuldade, acontece a passagem para a etapa seguinte: a desidentificação.

\subsection{TERCEIRA ETAPA: DESIDENTIFICAÇÃO}

Nessa etapa há um olhar em perspectiva, como dar um passo para trás e observar a situação com distanciamento. Aquilo que foi identificado na fase anterior já pode ser desidentificado. Após ter reconhecido e identificado em si certos padrões, o pianista já pode adotar uma visão em perspectiva. Retomando o meu exemplo com a balada de Chopin, houve o reconhecimento e a identificação dos aspectos negativos com relação a esta obra; a seguir, vem o momento de desidentificar, ou seja, eu não necessito mais desse padrão. Descubro que existe a dificuldade, mas eu não sou esta dificuldade. Portanto, permito a liberação desse padrão.

A situação de desidentificação pode ser analogamente descrita com a metáfora do elefantinho: quando pequeno, o filhote de elefante, ao ser treinado por um domador, fica amarrado por uma corda em uma pequena estaca, enterrada no chão. Após várias tentativas de se soltar, o pequeno elefante deixa de tentar, achando que "é impossível" escapar. Depois de adulto, o elefante continua preso pelo domador à mesma pequena estaca que o mantinha preso na infância. Obviamente o elefante adulto pode puxar a estaca pela corda e soltar-se facilmente. Entretanto, sua falta de experiência e autoconhecimento o impedem de utilizar sua enorme força para livrar-se da limitação. Comparo a minha situação com a balada de Chopin a esta metáfora, pois da mesma forma que o elefantinho, mantive na idade adulta os mesmos padrões adotados na infância, desistindo de tentar porque achava que seria impossível tocar no andamento "presto com fuoco".

$\mathrm{Na}$ etapa de desidentificação os obstáculos internos e externos na aprendizagem do trecho ou peça são evidenciados e ocorre uma contextualização: como deve ser 
tocado o trecho, quando, por que desta maneira, para que, onde etc. Pode-se inferir que há um amadurecimento quanto à interação do pianista com a obra e já não se trata mais da formação do vínculo, mas de um envolvimento que considera outros aspectos do objeto em estudo. Reflexões mais profundas sobre o conhecimento adquirido começam nesta etapa, quando outros elementos são valorizados e os elementos do desenvolvimento psíquico "sensação" e "intuição" predominam (SALDANHA, 2006).

O estudo contínuo vai aos poucos evidenciando certos aspectos dos quais há necessidade de desidentificação. A participação do professor nessa etapa é primordial, uma vez que já se encontra "do lado de fora", ou seja, desidentificado, em perspectiva. Desta forma, encontra-se em uma posição privilegiada de observador e pode visualizar o que o aluno ainda não consegue perceber nesse ponto do estudo. $O$ fato de o professor estar nessa posição consiste numa intervenção altamente benéfica no contexto do estudo, permitindo ao pianista alcançar resultados superiores àqueles que teria obtido sozinho, favorecendo a etapa da desidentificação. Observese que apesar de o pianista ter ciência de uma série de sugestões feitas pelo professor, ainda encontra-se identificado com outros desafios apresentados durante o estudo da obra, e não consegue perceber tais aspectos. Um exemplo disso ocorreu durante o estudo da Variação ํo 4, das Variações Corelli de Rachmaninoff que preparei durante o curso Recital de Mestrado, apresentada na Figura 4. 
Figura 4. Variação IV, de Variações Sobre um Tema de Corelli op. 42, de S. Rachmaninoff.
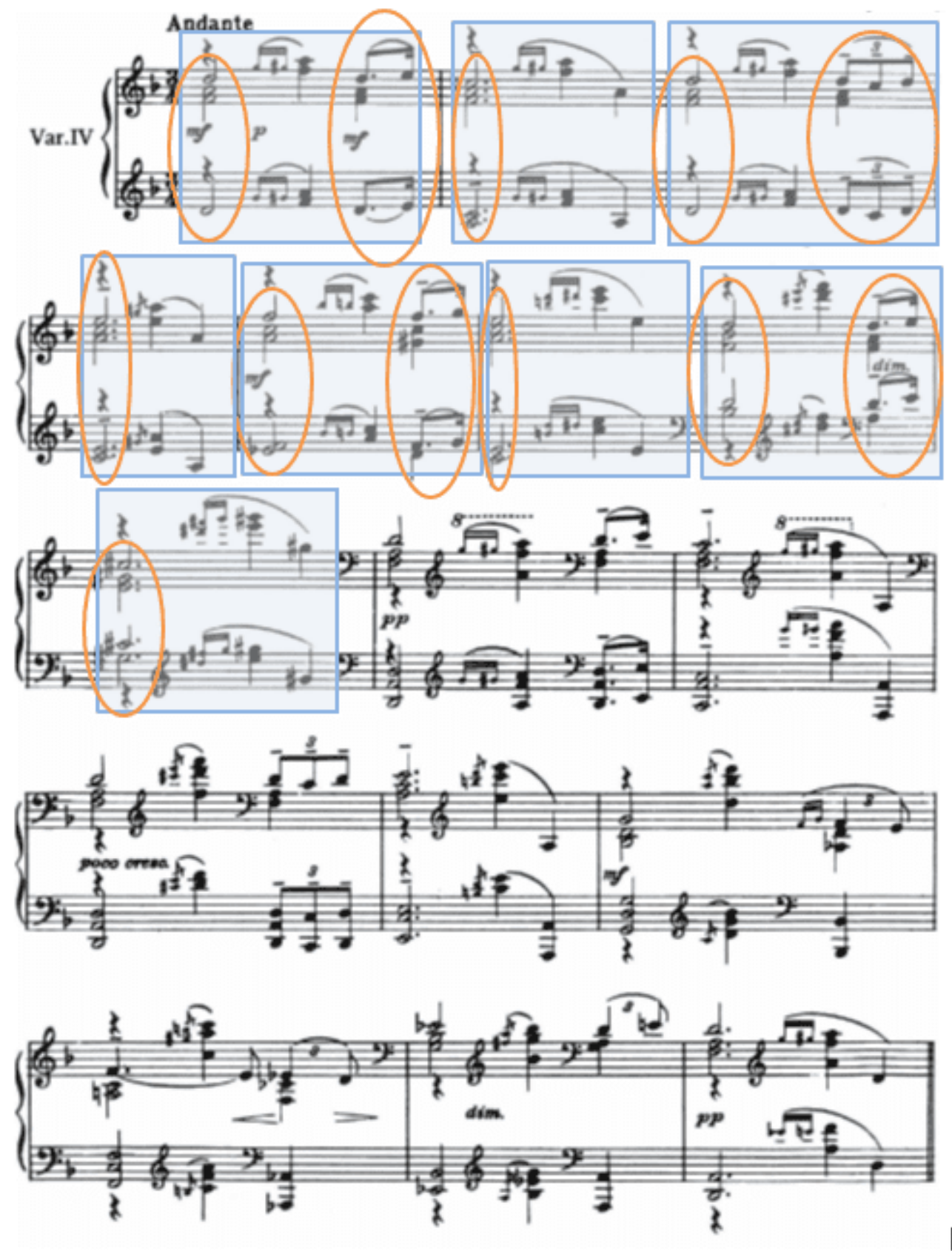

Fonte: imslp.org.

$\mathrm{Na}$ escrita para piano de Rachmaninoff é recorrente o uso de superposição de vozes em diversos planos, gerando uma textura densa e tecnicamente complexa, que requer do pianista a habilidade de realizar tais planos com independência e clareza. Apesar 
de eu estar ciente dessa configuração a partir da escrita do texto musical, minha execução não estava demonstrando isso. Em função da dificuldade inicial de fazer os deslocamentos e tocar as notas corretamente, além da interação do pedal, a ideia original do compositor manteve-se secundária nessa etapa do trabalho, e a definição dos planos não ficou evidente. Durante a aula de piano, minha professora apontou essa falha de leitura para que eu fizesse a correção. Imediatamente compreendi a necessidade de transição de uma etapa do estudo para a etapa seguinte, permitindo a desidentificação desse padrão e expandindo para uma perspectiva mais ampla em relação à obra.

A partir desse entendimento, busquei priorizar a clareza na definição dos dois planos principais, o que me levou a estudá-los separadamente, tocando primeiro os acordes que correspondem à condução do tema, abaixo grifados em laranja; num segundo momento toquei a área representada em azul corresponde aos elementos com função de ornamentação, sugerindo um tipo de toque mais leve do que o plano referente ao tema.

Trabalhei dessa forma durante duas sessões de estudo de 30 minutos, com intervalo de dois dias. A seguir, gravei a execução do trecho completo, e observei a eficácia do estudo empreendido. Desse modo, constatei a passagem da etapa da identificação para a etapa da desidentificação, nesse aspecto da interpretação.

Em minha experiência profissional como psicopedagoga clínica e professora de piano, percebi que existe uma tendência em permanecer no patamar de confluência entre identificação e desidentificação, sem conseguir consolidar a terceira etapa; ou ainda, de alcançar a desidentificação, desapegando-se de padrões limitadores, mas sem transcender para uma transmutação. Tal fato explica-se porque alguns fatores podem inibir a pulsão de transcendência, bem como impedir a ocorrência dos estados de platô/fluxo e experiências culminantes, interferindo na progressão do eixo evolutivo. Considero esses fatores como verdadeiros agentes sabotadores ${ }^{[14]}$, que criam uma toxina psíquica, potencialmente nociva ao pianista e o seu fazer artístico: a preocupação; a ansiedade; o cansaço geral; a exaustão em relação ao próprio estudo da obra; tensão, dificuldade de relaxar e pensar musicalmente; dentre outros. Em 
outras palavras, corroborando a Teoria da Motivação de Maslow, a satisfação das necessidades básicas do pianista consiste em um fator crucial para que possa atingir um estado mental durante a sua prática que esteja imune a esses agentes sabotadores, como se existisse um ambiente ideal psíquico para essa realização; do contrário, pode perder a oportunidade de alcançar níveis inimagináveis de desempenho e autorrealização.

Observe-se que o processo de desidentificação traz consigo uma liberação, com a energia necessária para a mudança de etapa, em direção à transmutação. Tecnicamente, ao liberar certos padrões limitadores o pianista pode realizar aquilo que seria impossível enquanto estivesse apegado a eles, já que houve uma ampliação de percepção com abertura para o eixo evolutivo e reflexões mais profundas acerca do conhecimento adquirido. Nesse momento, é favorecida a inteireza pessoal do indivíduo e são mais valorizadas a intuição e sensação; há uma abertura para níveis de perceptivos de maior sutileza, favorecendo o surgimento natural da etapa seguinte (SALDANHA, 2006).

\subsection{QUARTA ETAPA: TRANSMUTAÇÃO}

A importância de exercer plenamente as etapas de identificação e desidentificação na ação pianística permite que haja aprofundamento nesse processo, favorecendo a transmutação. O pianista já interiorizou os elementos de análise musical, definiu opções de interpretação e é possível que já retenha as notas na memória, podendo tocar como se estas "viessem de dentro dele" (de cor: do latim, do coração). Aqui o trabalho técnico ganha consistência, os padrões de movimento são estabelecidos, as pequenas mudanças preparam para a grande mudança (etapa seguinte, a transformação). Aspectos de dedilhado, compreensão da forma, fraseados, estrutura harmônica, articulações, estão em consolidação nesta etapa, onde "nada é inteiramente certo, nada é inteiramente errado ou inteiramente bom ou inteiramente mau" (id., ibidem). Ou seja, os ajustes estão sendo testificados, todas as mudanças são bem vindas, em uma infinita experimentação.

O conhecimento adquire significados pessoais, quando 
aspectos positivos , negativos, fáceis, difíceis, incitam a luta entre querer ir mais fundo e o abandonar, enquanto desafios da nova aquisição e as mudanças se impõem. (...) Inserem-se nesse momento também as funções da percepção concreta e abstrata, relacionadas à sensação e à percepção de síntese advinda da intuição (id., p. 163).

A transmutação ocorre em uma fase extremamente fecunda, repleta de oportunidades de aperfeiçoamento, trazendo um olhar mais amplo e novas perspectivas de aprendizagem inserindo não só a análise, o julgamento e a reflexão, mas os processos de percepção. É o momento da verificação, de aprimorar e embelezar cada detalhe, cada frase, cada passagem, onde o foco está nas infinitas possibilidades de sonoridades, articulações, intensidades; os aspectos artístico-musicais encontram nessa etapa um lugar destacado.

Em minha prática como pianista, observo que este é o momento em que as experiências de platô/fluxo começam a emergir, pois é aqui que o envolvimento mais profundo surge, uma vez que as barreiras iniciais foram vencidas. Mesmo que ainda não tenha memorizado a peça ou trechos dela, já consigo acessar a sua essência e fazer música.

Um outro aspecto da transmutação está relacionado às pequenas mudanças, aos câmbios. Na ação pianística observam-se as alterações sendo feitas em termos de sonoridade e resultados, substituindo passagens feitas anteriormente de uma maneira por uma nova, mais elegante, ou mais intensa, etc.

Vale ressaltar a importância de estar com a mente livre de barreiras que possam impedir a fluência de ideias e possibilidades inerentes ao processo criativo, de forma intrínseca ou extrínseca. Conforme o nível de necessidades básicas do pianista, tais barreiras podem tolher o seu processo de desenvolvimento, como a intervenção inadequada de um professor ou colega de trabalho (barreira extrínseca). O professor deve manter-se como um orientador nesse momento, permitindo que o aluno descubra a própria interpretação, ao invés de impor a sua maneira de tocar. Uma barreira de ordem intrínseca consiste em padrões internos de autoimagem distorcida, 
baixo nível de autoconfiança e autoestima, que inibem as iniciativas para a ação pianística. A fase de experimentação preenche diversas necessidades básicas e metanecessidades do pianista, e merecem ser respeitadas por colegas e professores. Entretanto, a atitude autoconsciente é que possibilita ao artista e aprender a lidar com tais dificuldades, amplamente favorável nessa etapa.

A possibilidade de observar o planejamento das ações e seus resultados práticos ao mesmo tempo em que observa as modificações no nível do ser é possível graças aos aspectos dinâmicos e práticos, previstos no corpo teórico da Abordagem Integrativa Transpessoal (AIT). Não há uma dissociação entre prática e teoria, mas uma interação dos eixos experiencial e evolutivo. As pequenas mutações são interatuantes e alicerçam o processo em direção à etapa seguinte.

\subsection{QUINTA ETAPA: TRANSFORMAÇÃO}

Este é o momento em que o pianista visualiza as etapas anteriores e verifica o quanto evoluiu na sua prática, ou seja, "percebe a situação atual transformada" (SALDANHA, 2008, p. 126). Depois de concretizar os pequenos câmbios, há um câmbio em grande proporção, uma alteração significativa, resultante do processo cumulativo das fases anteriores. A mudança de nível no desempenho ao executar a peça ou o trecho musical é evidenciada, proporcionando um redimensionamento dos aspectos já destacados durante a etapa anterior, tais como: dedilhado, compreensão da forma, fraseados, estrutura harmônica, articulações, andamento. A expansão de consciência amplia a capacidade de compreensão dos mesmos elementos, em um novo contexto que compreende uma síntese das etapas anteriores, onde a fragmentação deixa de existir. De acordo com Saldanha,

Didaticamente houve uma passagem, uma mudança de nível, de ordem estrutural da informação. Ela já é uma aquisição diferenciada, traz um novo referencial interno e externo para o indivíduo (id., p. 227).

A autora enfatiza que há uma transformação do conhecimento em sabedoria diferenciada, interiorizada, experienciada, contextualizada e compreendida (idem). 
Esta fase é gratificante para o pianista, podendo levá-lo a crer que o trabalho está terminado, uma vez que já atingiu os principais objetivos, ou seja, alcançou a autorrealização, conforme a pirâmide das necessidades de Maslow. A sensação de dever cumprido, de uma meta alcançada, possibilita ocorrências frequentes de estado de platô/fluxo, devido ao imenso prazer experimentado nessas situações, podendo chegar ao êxtase, em situações de experiências culminantes e favorece a emergência da fase seguinte. Por outro lado, conforme a interatuação dos eixos experiencial e evolutivo, pode haver uma certa mecanização da execução, como se não houvesse mais nada a fazer em termos de interpretação. Nesse caso, não há a pulsão de transcendência, pois o eixo evolutivo encontra-se em um grau aquém do necessário. Desta forma, é indicado que se abandone temporariamente o estudo da peça, para retomar novamente num outro momento, tirando proveito da "incubação" ${ }^{[15]}$ inerente a esse estado de latência.

Esse fenômeno é familiar aos pianistas profissionais. A pianista Gabriela Immreh participou como sujeito do importante estudo realizado pelo psicólogo Roger Chaffin (2003) sobre memória e prática pianística e relatou, a respeito do estudo do terceiro movimento do Concerto Italiano, de Bach, que quando voltou a tocar, depois de alguns dias afastada do piano, percebeu ter renovado suas ideias.

Esse "olhar para trás e perceber a mudança" é determinante para preparar a próxima etapa. É como dizer que agora é que vai começar o verdadeiro processo transcendental. Para o artista que busca a verdadeira transcendência através da música, são as próximas etapas que oferecem as perspectivas de alcançar uma interpretação no nível da metarrealização.

\subsection{SEXTA ETAPA: ELABORAÇÃO}

Nesta etapa os fatores técnicos já foram vencidos, o que permite ao artista tocar sem ocupar sua energia primordial para a resolução de problemas. As memórias cinestésica, analítica, visual e auditiva interagem, liberando a atenção para um novo patamar, no qual apenas mantem-se o controle das ações ao piano, sem necessitar reconstruir a cada momento os padrões estruturais da execução, que já estão prontos. 
Esta fase oferece o suporte psíquico para a ocorrência do estado de platô/fluxo e experiências culminantes. Aqui, o pianista está livre de preocupações em sua execução, pois a obra está completamente internalizada. A extrema fluência com que realiza a ação pianística faz com que a conexão com o estado de platô/fluxo ocorra imediatamente. Os flashes intuitivos ficam mais frequentes e devem ser considerados pelo pianista como informações valiosas que emergem do supraconsciente para tornar sua interpretação cada vez mais madura e, principalmente, pessoal, sem preocupações e outras interferências.

De acordo com Saldanha, na etapa da elaboração, advinda da própria transformação proveniente dos insights da nova aquisição, há uma apreensão global da situação e das possibilidades, promovendo o novo, diferenciado; o sentido do novo, de uma nova dimensão do contexto pessoal, social, espiritual e o sentido da experiência em seu eixo experiencial e evolutivo, "uma apreensão do verdadeiro conhecimento e do sentido desse saber na vida do indivíduo" (id., p. 164). A emergência dos valores "S" descritos por Maslow faz-se presente nessa etapa, quando o pianista consegue elaborar conjecturas filosóficas e espirituais entre a música e a existência, utilizando uma linguagem própria das experiências transcendentes. Certos músicos permanecem longas faixas de tempo nesse estado de consciência expandido, o que propicia um elevado grau de produtividade e criatividade, além de ser repleto de insights.

Um exemplo contemporâneo desse perfil é o compositor, regente, violinista, pianista e professor finlandês Lief Segerstam (1944-), compositor de mais de 200 sinfonias e com uma intensa atuação como regente. Ao ser questionado em entrevista sobre a administração do tempo e sua capacidade produtiva incomum, declara em entrevista transcrita abaixo ${ }^{[16]}$ :

O tempo não existe. Tempo é o meio que se usa depois do processo criativo para medir e comparar as obras, mas o tempo não existe. As coisas acontecem, as sinfonias são escritas, e eu só seleciono as tonalidades. Mas as 12 tonalidades estão disponíveis para todos, como estiveram para Mozart, Beethoven, Rimsky-Korsakov, Segerstam ou 
Sibelius. Escolhemos as mesmas tonalidades e fazemos combinações interessantes que são parte da natureza, e a força da natureza se mistura a essas tonalidades. Em minha música, há tonalidade livre, pulsação livre, tonalidade complexa, pulsação complexa... Se há 28 linhas em papel pautado e fazemos pulsação livre, podemos ter 28 pulsações diferentes ao mesmo tempo, e para reger eu teria de ser um polvo! Eu não posso ser um polvo! Sério: não há nenhum regente, o mecanismo de regência está embutido em cada grupo sinfônico e em cada músico. Temos que ser flexíveis com a verdade, como na vida. Todos estamos escrevendo nossa sinfonia, e a partitura é a homepage para o selecionador das tonalidades. Escolho as tonalidades e as atribuições. (O entrevistador faz um aparte: 'Mas, 200 sinfonias?!'). Sim, mas é como no cultivo do vinho, no qual há anos melhores e outros piores. Para mim, o último ano foi muito bom para minhas sinfonias, mas não para minha partitura de vida, pois pensei que iria morrer por causa do câncer. Não tenho nada e compus 14 sinfonias no verão em que recebi o tratamento. Agora estou aqui, muito bem em meus exames de laboratório. Estou um pouco grande (pesado), mas meu sorriso é maior do que era antes.

As correlações feitas por Lief Segerstam denotam a vivência em situações de transcendência, em função da capacidade de estabelecer analogamente a complexidade da vida com a estrutura musical, o que para ele parece ocorrer de forma simples e fluente, sem esforço. Verifica-se em seu relato a presença da maioria dos valores "S": Verdade, Beleza, Plenitude, Transcendência da dicotomia, Vitalidade, Unicidade, Perfeição, Necessidade, Culminância, Ordem, Simplicidade, Riqueza, Facilidade, Diversão e Autossuficiência, ultrapassando o preenchimento das necessidades básicas, alcançando as metanecessidades.

A atitude autoconsciente e o uso das habilidades metacognitivas favorecem consideravelmente a etapa da elaboração. Tal qual descreve o compositor Robert Schumann: 
Se o Céu te concedeu uma imaginação fértil, então passarás frequentemente horas solitárias ao piano, como em transe, procurando as harmonias para exprimir os teus sentimentos mais profundos. Sentirte-ás tanto mais imerso num círculo mágico, quanto mais desconhecido for para ti o mundo da harmonia. Essas são as horas mais felizes da juventude. Mas tem cuidado para não alimentares um tipo de talento que te pode levar a perder tempo e energia em fantasmas da imaginação. $O$ domínio da forma e a capacidade de formular pensamentos de forma clara apenas podem ser adquiridos através dos símbolos fixos da notação. Escreve, pois, mais, e sonha menos. (...) Talvez apenas os gênios sejam capazes de compreender os gênios. (SCHUMANN, 1979).

O transe relatado por Schumann consiste no estado de consciência expandido, em um espaço psíquico característico das etapas de elaboração e integração. Ressaltase que esse estado nada tem a ver com experiências de devaneio, mas de uma plena consciência. A aparente "ausência" propiciada por esse estado de consciência pode provocar uma alteração no comportamento do artista e ser equivocadamente interpretada como misantropia ou até mesmo, algum tipo de arrogância. De fato, ao invés de ausência, ocorre um verdadeiro "mergulho" no próprio psiquismo, de uma forma saudável e motivada por pulsões de transcendência, ancoradas por habilidades metacognitivas que monitoram e regulam esse processo. A interação com a sétima etapa é então evidenciada.

\subsection{SÉTIMA ETAPA: INTEGRAÇÃO}

Nesta etapa ocorre a "integração do conhecimento na vida pessoal, profissional e cotidiana, mas agora já inserido em todo o ser. O indivíduo jamais será o mesmo" (id., p. 177). A jornada das etapas anteriores conduziu o pianista a esse conjunto de situações em que alcança a plenitude: a excelência da ação pianística integrada ao ser autoconsciente. Ele torna-se um só com a obra e com o instrumento. Para Saldanha, 
Quanto maior a aprendizagem, maior essa consciência de integração, mais plena, nas várias dimensões do ser, nas distintas áreas da vida do indivíduo (...). Essa dinâmica natural de integração e apreensão do conhecimento é o que o torna um instrumento vivo, parte íntima do processo transformador e revelador da vida humana, contribui no nível social e coletivo, ao mesmo tempo, em que dá sentido à existência (id., ibidem).

Um exemplo de integração como a sétima e última etapa deste processo na prática pianística é o momento da apresentação pública da obra estudada, desde que tenha vivenciado as etapas anteriores e esta seja o ponto culminante. Em outras palavras, se o pianista venceu transcendeu de uma a outra etapa e o final desse percurso resulta em um recital, é possível que alcance o nível da integração de todos esses componentes. Durante o recital, o pianista tem a oportunidade de rever cada etapa de forma integrada e multidimensional. A situação de estar em público potencializa o risco de acontecer o erro, a distração, a perda do foco, fatores que geram a produção extra de adrenalina, inundando a corrente sanguínea, alterando os batimentos cardíacos e trazendo outros sintomas desagradáveis conhecidos (sudorese, boca seca, tremor, etc.). Tais fatores podem se converter em agentes sabotadores e impedir a ocorrência da integração, caso o pianista mantenha-se identificado com o medo de não conseguir, com o medo de errar. Para evitar uma experiência mal sucedida, é importante manter a atitude mental adequada durante a apresentação em público. $\mathrm{Na}$ perspectiva da abordagem integrativa transpessoal, a sétima etapa

agrega valores no âmbito pessoal e social, os quais favorecem a capacidade de autorregulação e aprimoramento contínuo do saber, motivando-o a novos conhecimentos e ciclos de aprendizagem diferenciada (SALDANHA, 2008, p. 223).

Por essa razão, considera-se que os resultados, sejam eles quais forem, sempre serão positivos, uma vez que a jornada em direção ao recital é mais importante do que a chegada. A sétima e última etapa traz consigo o germe de um novo ciclo, uma primeira etapa. Portanto, em uma abordagem integrativa transpessoal, o papel do 
artista nesse processo está vinculado a outras questões, as quais ultrapassam o ego, a persona, do pianista.

De acordo com o filósofo catarinense Huberto Rohden, é na ausência do "Ego-Agente" que o artista passa a ser "Cosmo-Agido", servindo de canal para dar vazão a uma "Fonte Creadora" (ROHDEN, 1966) ${ }^{[17]}$. Em outras palavras, o artista, no momento em que se encontra no palco, deve deixar de lado as atribuições que o definem como persona: títulos, nome e sobrenome, papéis exercidos na família, etc. Desta forma, estará praticando o "não agir", servindo de canal para a manifestação plena de algo que envolve o instrumento, a obra musical, o compositor, o público e o seu próprio ser, em detrimento de seu ego-agente, conduzindo a uma experiência de integração. Sobre a postura do intérprete, o compositor e regente Lief Segerstam relata em entrevista que

o intérprete é o responsável, o embaixador do compositor e o representante do público e está em um lugar idôneo para interatuar. Tentamos fazer com que os músicos se conectem, e quando a música começa a existir, é vida, e vida é música! Música é inextinguível![18]

Obviamente, nem toda a apresentação pública de uma obra pianística consiste na etapa de integração do processo didático-transpessoal do intérprete. O roteiro que traçamos, com base na classificação da didática transpessoal, sugere um percurso ideal de superação e autodesenvolvimento em sete etapas.

Um exemplo disso foi o recital que apresentei no final do curso de Mestrado. Ao longo dos dois anos preparei um repertório do qual constaram peças com as quais tenho diferentes tipos de vínculo: toquei a rapsódica "Impressões Seresteiras", de H. VillaLobos como peça brasileira, as Variações sob um tema de Corelli, de $\mathrm{S}$. Rachmaninoff, três Intermezzi opus 118 (2,4 e 6), de J. Brahms, e a Balada no 1, de F. Chopin, nessa ordem. A peça de Villa-Lobos é bastante familiar para mim, ao contrário da colossal obra de Rachmaninoff, com a qual nunca havia tido contato. Já as peças de Brahms são bastante representativas quanto ao meu perfil de pianista, pois que tenho grande afinidade com esse compositor. A Balada de Chopin possui em 
minha vida um histórico que iniciado na infância, conforme relatado anteriormente. Retomando a ideia de que "o indivíduo jamais será o mesmo", percebo que, nesse sentido, alcancei a sétima etapa. Desde o meu primeiro contato com as Variações de Rachmaninoff experimentei diferentes estágios emocionais e sensoriais: medo, euforia, ansiedade, arrebatamento, juntamente com fadiga muscular, esgotamento mental, dores lancinantes nos punhos.

Superadas as dificuldades, com o passar do tempo e consequente amadurecimento, observei que tais "provações" serviram como uma espécie de "rito de passagem", para que eu estivesse apta a alcançar a elaboração e integração. De fato, na dimensão psicológica, atingi esse nível. Apesar de ter tido algumas falhas de memória durante o recital de final do curso, fiquei bastante satisfeita com o fato de ter alcançado esta integração, que representa a sétima etapa. Tal dimensão ultrapassa qualquer convenção burocrática - como uma pontuação por nota alta ou baixa, pois diz respeito ao meu processo interno de evolução e transcendência. Essa postura diante do evento está em conformidade com o indicador de fluxo "perda do ego", no qual os títulos, as convenções sociais e identificação com a própria persona deixam de ser prioridade. Nesse patamar, o que realmente importa é saber o quanto houve de autoatualização, o quanto "jamais serei a mesma" depois dessa experiência. Importa também receber os relatos emocionados de pessoas que alcançaram o estado de platô/fluxo ao assistir o recital. Ou seja, aquilo que representou minha própria integração favoreceu a autoatualização em outras pessoas.

Percebi então o que realmente significa a integração, e esta pode ocorrer em níveis que ultrapassam nossa compreensão intelectual do fenômeno. A autorrealização/autoatualização consolida-se; a minha capacidade consciente aprimoramento em diferentes dimensões do meu Ser através da prática pianística permite o encontro com aquilo que para mim é essencial e me torna única. 


\section{RESULTADOS}

- Foi possível verificar o eixo evolutivo e eixo experiencial atuando concomitantemente durante o processo das sete etapas de meu envolvimento com as obras musicais estudadas;

- O modelo em sete etapas da AIT favorece a compreensão da ocorrência de diferentes pensamentos, emoções, insights e sensações (REIS) a partir da habilidade metacognitiva de autoconsciência;

- No nível do supraconsciente, quando as informações emergem como intuições, surgem orientações específicas quanto às estratégias cognitivas e metacognitivas e assim observou-se a evolução no desempenho nas peças;

- Constatou-se a existência de situações de fluxo conforme descrição dos indicadores de Mihaly Csikszentmihalyi;

- Verificou-se o aspecto transcendente de autoatualização proposto.

- Observou-se a importância de manter-se autoconsciente com relação ao processo completo do fazer musical, ou seja, dos aspectos técnicos, artísticos, físicos, afetivos;

- É possível atingir o nível da metarrealização no momento em que os pensamentos autorrealizadores se manifestam, mas em momentos de curtíssima duração. por Maslow;

- O processo de desenvolvimento em sete etapas da AIT é dinâmico e não estanque. Enquanto alcança a última etapa já traz o novo ciclo, recomeçando a partir de um novo reconhecimento.

\section{CONSIDERAÇÕES FINAIS}

Este trabalho teve por objetivo focalizar aspectos de "transcendência" como componentes do processo de estudo de um repertório para piano à luz de um modelo fornecido pela Abordagem Integrativa Transpessoal (AIT). O percurso das sete etapas descritas na AIT foi descrito em profundidade, e ficar claros os estágios de Reconhecimento, Identificação, Desidentificação, Transmutação, Transformação, Elaboração e Integração. 
Os resultados demostraram que a metacognição possibilita a autoconsciência necessária à percepção da dimensão transcendental da prática pianística. Esse processo permite ao pianista experimentar verdadeiros saltos nessa jornada de autodescoberta, em busca da excelência no desempenho artístico e pessoal.

Os processos de aprendizagem musical que consideram os estados alterados de consciência são ainda pouco explorados enquanto pesquisa científica. Desta forma, este trabalho traz à luz questões pertinentes, que podem estimular pesquisadores a avançar nesse campo de estudos.

\section{REFERÊNCIAS}

ASSAGIOLI, Roberto. Psicossíntese: as bases da psicologia moderna e transpessoal. 2. ed. - São Paulo: Cultrix, 2013.

. Ser Transpessoal. España: Gaia, 1993, 334p.

BARROS, Luís Cláudio. A pesquisa empírica sobre o planejamento da execução instrumental: uma reflexão crítica do sujeito de um estudo de caso. Tese de doutorado UFRGS, Porto Alegre: 2008.

CHAFFIN, Roger; IMMREH, Gabriela; LEMIEUX F., Anthony \& COLLEEN, Chen. "Seeing the Big Picture": Piano Practice as Expert Problem Solving. Music Perception. Vol. 20, No. 4, 465-490. University of California: 2003.

CORTOT, Alfred. Édition de Travaille des OEvres de Chopin. Salabert: Paris, 1929. . Curso de interpretação. Brasília, DF: MusiMed, 1986. 179 p.

CSIKSZENTMIHALYI, Mihaly. A psicologia da felicidade. São Paulo: Saraiva, 1992.

. Gestão qualificada: a conexão entre felicidade e negócio. Porto Alegre: Bookman, 2004. 
. Flow: the psychology of optimal experience. New York: HarperCollins, 2008.

MASLOW, Abraham Harold. Religions, Values, and Peak Experiences. Columbus: Ohio State University Press, 1964.

. Motivation and Personality. $2^{\mathrm{a}}$ ed. New York: Harper e Row, 1970.

. The Farther Reaches of Human Nature. England: Penguin Compass, 1971.

. La personalidade creadora. 9ª ed. Barcelona: Kairós, 2008, 480p.

MATURANA, Humberto; VARELA, V.F. A árvore do conhecimento: as bases biológicas do entendimento humano. Campinas: PSYII, 1995

PÓVOAS, Maria Bernardete Castelan. Controle de Movimento com Base em um Princípio de Relação e Regulação do Impulso-Movimento: Possíveis Reflexos na Otimização da Ação Pianística. Tese de Doutorado. UFRGS, Porto Alegre, 1999.

. Ciclos de Movimento - um recurso técnico-estratégico interdisciplinar

de organização do movimento na ação pianística. In: Anais XVI Congresso da Associação Nacional de Pesquisa e Pós-graduação em Música (ANPPOM). Brasília, 2006. p. $665-670$.

Ação pianística, desempenho e controle do movimento: uma perspectiva interdisciplinar. In: Anais do III Simpósio de Cognição e Artes Musicais. Salvador: EDUFBA, 2007. p. 540-548.

. Desempenho pianístico e Rodízio: um sistema de organização do estudo baseado na distribuição e variabilidade da prática. In: Anais XXV Congresso da Associação Nacional de Pesquisa e Pós-graduação em Música (ANPPOM). Vitória, 2015. 
PRIVETTE, Gayle. Peak experience, peak performance, and flow: A comparative analysis of positive human experiences. Journal of Personality and Social Psychology, 45, 1983, p. $1361-1368$

ROHDEN, Huberto. Filosofia da Arte:a metafísica da verdade revelada na estética da beleza.São Paulo: Freitas Bastos, 1966.

. Einstein, o enigma da matemática. 3ạ. ed. São Paulo: Alvorada, 1980.

SALDANHA, Vera. Didática transpessoal: perspectivas inovadoras para uma educação integral. Campinas, SP; Universidade Estadual de Campinas; Faculdade de Educação; Depto de Desenvolvimento Humano, Psicologia, Educação, 2006 (Tese de Doutorado).

- Psicologia Transpessoal: abordagem integrativa: um conhecimento emergente em psicologia da consciência. ljuí: Editora Unijuí, 2008.

SCHUMANN, Robert. Album für die Jugend Op.68. Wiener Urtext Edition, Viena: 1979. WEIL, Pierre. A morte da morte. São Paulo: Gente, 1995

WILBER, Ken. A Visão Integral. Editora Cultrix, São Paulo: 2010.

- Entrevista:

MARIA JOÃO PIRES. Disponível em https://www.youtube.com/watch?v=lu1aWSCMPTA Acesso em 20/01/2019. Dur: 08:04. (Entrevista realizada durante o masterclass com a pianista Maria João Pires).

- Entrevista:

LIEF SERGERSTAM. Disponível em http://www.youtube.com/watch?v=gtX9|ryMcEo acesso em 20/01/2019. Dur: 14:40. (Entrevista realizada com o compositor e regente Lief Segerstam).

- DVD: 
NELSON FREIRE: Um filme sobre um homem e sua música. Direção: João Moreira Salles. Produção executiva: Maurício Andrade Ramos. Videofilmes Produções Artísticas, 2003. DVD (102 min).

- Partitura web:

CHOPIN,

Frédéric.

Ballades.

Disponível

em

http://imslp.eu/Files/imglnks/euimg/2/2a/IMSLP73959-PMLP01646-

Chopin_Paderewski_No_3_Ballades_Op_23_filter.pdf acesso em 20/01/2019.

RACHMANINOFF, Sergei. Variations on a Theme of Corelli (1931). Disponível em http://imslp.eu/Files/imglnks/euimg/d/d7/IMSLP02058-Rachmaninoff

Corelli_Variations.pdf acesso em 20/01/2019.

2. No referencial teórico de Maslow, o termo "autoatualização" corresponde ao termo "autorrealização" e ainda ao termo "individuação" e consiste em uma alteração positiva no comportamento do indivíduo após as situações de expansão de consciência proporcionadas pelos estados de platô/fluxo e experiências culminantes.

3. Disponível em https://www.youtube.com/watch?v=lu1aWSCMPTA Acesso em 20/01/2019 Dur: 08:04.Entrevista realizada durante o masterclass com a pianista Maria João Pires.

4. Segundo Jung, o tipo psicológico do indivíduo determina sua maneira de se relacionar com o mundo interior e exterior, as pessoas e as coisas, o que ocorre por meio de uma atitude de extroversão ou introversão relacionada às funções do pensamento, sentimento, sensação e intuição. A atitude refere-se ao movimento predominante da libido, ou seja, da energia psíquica, na qual a extroversão indica a consciência do individuo voltada para os objetos ou mundo externo, e a introversão, uma orientação para o mundo interior da psique. As funções psíquicas são os recursos através dos quais a consciência obtém orientação para a experiência e compõem, no total, oito tipos de caráter, com distintos graus entre essas combinações de atitudes e funções psíquicas, segundo Jung" (SALDANHA, 2006, p.129). 
5. SALDANHA, 2008, p. 186-194.

6. MATURANA, Humberto; VARELA, V.F. A árvore do conhecimento: as bases biológicas do entendimento humano. Campinas: PSYII, 1995.

7. Hierarquia das necessidades básicas: fisiológicas (fome, sono, etc.); segurança (estabilidade, ordem); amor epertinência (família, amizade); estima (respeito, aprovação); autoatualização (desenvolvimento decapacidades, plenos talentos, potencialidades).

8. Documentário em DVD "Nelson Freire: um filme sobre um homem e sua música" dirigido por João Moreiran Salles (2003).

9. Ciclos de movimento são derivações do "princípio da relação e regulação do impulso-movimento",formulado pela pianista e pesquisadora $\mathrm{M}^{\mathrm{a}}$ Bernardete Castelan Póvoas (PÓVOAS, 1999, p. 87).

10. Catarse: Em Psicologia, a catarse consiste na liberação de emoções reprimidas e possui um sentido depurificação.

11. Carência básica: quando uma necessidade básica da pirâmide de Maslow não é satisfeita, torna-se umacarência básica, e conforme o grau de intensidade, pode tornar-se uma neurose.

12. Fechamento da Gestalt: o princípio de que algo se completa, as partes se integram formando o todo.

13. Em latim, fiat significa fazer ou feito.

14. Agentes sabotadores: expressão cunhada pela autora referente aos múltiplos fatores de ordem intrínseca e extrínseca que interferem no processo de alcançar estados de platô/fluxo e experiência culminante. Podem surgir através de comentários e atitudes de pessoas próximas, de colegas ou até mesmo do professor;podem ainda ser gerados por pensamentos recorrentes do próprio pianista, tornando-se crenças equivocadas e contraproducentes. 
15. Incubação: na ótica da psicologia transpessoal, no período de incubação os elementos trabalhados anteriormente no nível consciente passam a exercer sua atividade num outro nível de consciência.

16. Disponível em http://www.youtube.com/watch?v=gtX9IryMcEo acesso em 20/01/2019.

17. Em seus mais de 60 livros publicados, Huberto Rohden escreve num prólogo a seguinte advertência: "A substituição da tradicional palavra latina crear pelo neologismo moderno criar é aceitável em nível de cultura primária, porque favorece a alfabetização e dispensa esforço mental - mas não é aceitável em nível de cultura superior, porque deturpa o pensamento. Crear é a manifestação da Essência em forma de existência - criar é a transição de uma existência para outra existência. $O$ Poder Infinito é o creador do Universo - um fazendeiro é criador de gado. Há entre os homens gênios creadores, embora não sejam talvez criadores. A conhecida lei de Lavoisier diz que "na natureza nada se crea e nada se aniquila, tudo se transforma", se grafarmos "nada se crea", esta lei está certa mas se escrevermos "nada se cria", ela resulta totalmente falsa. Por isto, preferimos a verdade e clareza do pensamento a quaisquer convenções acadêmicas" (ROHDEN, 1966, p. 5).

18. Disponível em http://www.youtube.com/watch?v=gtX9lryMcEo acesso em 20/01/2019.

Enviado: Janeiro, 2019.

Aprovado: Agosto, 2019. 